\title{
The Implementation of Mind Mapping Technique to Improve Mandarin Students' Systematic Thinking Skills
}

\author{
Subandi \\ Universitas Negeri Surabaya \\ Surabaya, Indonesia \\ subandi@unesa.ac.id \\ Kato Yoshinori \\ Osaka University of Health and Sport Sciences \\ Osaka, Japan \\ yykatoy@ouhs.ac.jp
}

\author{
Sakakibara Chizuru \\ Nagoya University \\ Nagoya, Japan \\ chizuru@nagoya-u.jp
}

Galih Wibisono

Universitas Negeri Surabaya

Surabaya, Indonesia

galihwibisono@unesa.ac.id

\begin{abstract}
Shaping students' systematic thinking ability in the educational world is one common issue that happens in every stage of education. Mind mapping technique is proven to help students constructing their systematic thinking. It is caused that mind mapping enables students to remember the saved concepts idea in the memory to disclose back in a systemic and coherent way. The mind mapping technique is applied when students are arranging a scientific research to fulfill their duty. It requires them to represent their findings as well as to be responsibe toward the their works. The students are in this case helped to propose the idea and thought either in written like in the form of their articles or in oral like presenting their works. The presented whole idea is complete and in regular basis that portrays the series of event that creates unified term. The idea and information sharing can perfectly be done by students. This is a prove that mind mapping contributes a positive outcome in the process of constructing students' systematic thinking ability . The constrains that arise can still be solved by looking back at thinking scheme that has been conceptualized in the mind mapping prototype. It eases students to do not seek back the concepts idea from the beginning.
\end{abstract}

Keywords-Constructing; systematic thinking; emotional center; linked concept

\section{INTRODUCTION}

It is no easy to achieve the learning goal because learning is an activity that implicates many aspects like joining together the students' behavior and character, cognitive aspect, and the intellectual aspect.

Learning as an activity to educate a conceptual knowledge can be enabled as the change of behavioral center, characters, and students' mindset. For that reason, it is stated that learning is a kind of complicated and complex process which in its implementation must be sustainable. It is implied that the process should run continually because the science principle is tiered.
Learning is a scheduled and not spontaneous manner. It needs to be prepared like in case of determining the students' target competency and deciding an exact technique in order to process a successful, good, and arranged learning. In connection to that issue, it has been explained that the learning process is a behavioral changing process through individual and environmental interaction where she or he belongs. It is seen as a series of sustainable, planned, gradual, rotational, balanced and integrated event [1] \& [2]. That thing supports the argument that behavioral and mindset changing from students as an individual is a result of a learning process that is sustainable and regular. It is eventually resulted to students' life quality improvement as a whole in case of cognitive aspect that specifically concerns on intellectual, skills, and behavior.

The education in the end has to be able to bring students into interactional competence, social competence; also has be able to shape the attitude and moral [3]. Moreover, it has to be able to make an easier and meaningful life. The consequences of those previous statements require stakeholder to prepare the learning techniques that is more exact and appropriate which are also should be in line with the students' characteristic and standard competency.

To support the learning achievement, there are several things should be considered, one of those is choosing the relevant learning techniques. There are many learning techniques; one of them is mind mapping which is found by Toni Buzan. It is used to bring up students past memory [4]. It is said so because bringing up students past memory enables students to remember the all subjects learnt. That makes sense that the main purpose of mind mapping is to help students in remembering the subjects they are encountering. Mind mapping is also hypothesized to help students constructing a systematic thinking schema. This happens because mind mapping is able to give students view of the related image of all aspect that is sequential and interrelated.

It is in line with what has been expressed that the mind mapping's supremacy is lied on much better citing process, fun 
and interesting, the needed time to re-learn is relatively shorter and the recall is much better [5]. Moreover, it has been stated that human brain can save images and meanings not the words. In this case, images can stimulate the brain emotional center [6]. For that specific reason, mind mapping technique is considered as an effective technique that helps students to improve memory, and shaping systematic mindset. That happens because mind mapping provides images view in sequence and has a continuous relation as well as linking the previous and the following images. The relationships help students to connect an idea or event in the right order and coherence to make a whole and integrated plot of a story or phenomenon.

\section{LITERATURE REVIEW}

\section{A. Mind Mapping and its role}

Mind mapping technique is developed by Tony Busan. Mind mapping is one of recoding techniques in either past event and/or a recoding to an event in the next which employs images, symbols and word in a sheet of paper. The main idea is put in the middle of the paper which expands into branches, or twigs. Those branches or twigs are given a specific images, symbols or words as the description of the main concept. Those twigs portray the connection and interconnection between aspects that form the main idea. The twig represents the elaboration of the main idea that form a series of plot which is connected each other. The images and color variation makes the form much more interesting that leads students to do a better retention in their memory. As a result, it does help the students' comprehension and memory. Like what has been written that students' interest toward a learning process does really support the learning achievement [9]. Furthermore, it is also stated that mind mapping is really helpful to make notes or records, list of activities or goods, do planning, and presenting the idea or thought [10]. It is why mind mapping is seen as a part of important life. Those above argument or statement can be said that the learning approach that attracts students can contribute to positive motivation that eventually leads students to do better learning and studying. Mind mapping has a various symbols that are strung together with branches as its characteristic. It is assumed that this feature magnetizes students' interest. There was also a statement which explained that mind mapping does not only function as problem organizer, but it also very effective to increase memory and understanding also it can increase students' skill in presenting the idea or thought [9]. Furthermore, it has been stated that the human brain cannot save words in direct manner, but it can be saved through linking with the imagination, color, symbol and other that are easy to be remembered [8]. From those two prominent arguments, it is assumed that human brain is much more sensitive to stimulation like images, symbols, or concrete things with specific colors. This is happening because symbols, color, images, or things become one of the forming components of mind mapping that is concrete which can be seen by sense of sight. As the result, those components are easier to be kept in the human brain. It is different with the words which have no physical appearance and abstract. It leads human to easily forget it. Those concepts are then implemented in the mind mapping which employs images and color as the shape of the addressed object in each twig as the images sign.
Those objects have linked concepts which are presented in the mind mapping schema to be captured by human brain. Symbols, images or sign used in the mind mapping have conformity with the human brain mechanism. Human brain is curious and will respond to the interesting objects. It is in line with a statement, which stated that human brain is motivated and interested toward any attracting objects or data [10]. It is resulted to better brain working to respond the data accepted; there will be easier and faster brain working. By employing images symbols, or colors surrounding, it is assumed to attract students' desire to learn.

Mind mapping is also able to fulfill the desire and needs of human brain characteristic. Because of its conformity factor, human brain is able to accept and save the objects or data so that we are able to remember and state it back. This issue has been supported with a statement that the recognized object will easily be remembered in a very short relative time and can possibly be stated back by implementing mind mapping [11]. This thing means that human brain is doing preparation to insert the new information. By such working mechanism, it is indicated that mind mapping is in line with the human brain working mechanism. The data displaying technique in mind mapping helps brain to work in order to find and reveal everything back in sequence, coherence, and comprehensive that creates the systematical series events.

\section{B. Mind Mapping and thinking systematic}

Thinking process is an activity which is done by every human in every standard and normal mental condition; starting from the simplest thinking activity to the complicated higher thinking. Even the thinking process is simple, if it is not managed with the good concepts and is not prepared its stage, there will be such complicated event and it will takes more time than it should be. It has been stated that a simple activity can be seriously complicated, therefore it needs such steps to learn and think [12]. Moreover, it has been proposed the conditioning theory in which it deals with the conditioning process to build series of response of stimulus connection and complex behavior that is learnt through series or series of responses [12]. It can be stated that concepts, idea, thought, and or any information that are going to be uttered if they are situated in a series, they will be much easier to be presented. If this concept is applied in the learning activity especially language learning, conditioning can be performed by means of conveying the idea or thought [13] \& [14].

Realize or not, conditioning will be performed before doing such activity to prepare everything that is going to be said. The conditioning is done in order for students to do a well arranged activity, composing a systematic result that eases other people who are involved in the activities and roles as partners. Based on the above logical thinking, it is assumed that it is very relevant if mind mapping is applied. This is because human brain tends to save any fun experiences like playing element, something structured and concrete. Like what has been explained above, mind mapping is a concrete learning model that is believed as a fun model of learning because students are in this case involved to play within its implementation. They are getting involved with mapping their mind map that is actualized in the form of images, symbols, or and words that make students feel encouraged, feel fun, and feel joyful. If 
those fun situations are kept within, students in the end will think the learning process as a fun experience that leads them in easily remembering. Like what has been proposed before, that game or playing in the process of learning enables students to not only feel happy but it also helps them in the learning concepts [15] \& [16]. As a result, the fun learning technique at the same time can build students interest, motivation, and good response due to playing aspect that is packed within implementing of mind mapping. Students are in this case guided to follow the student-centered model that allows them to be active learners. It is expected that students' potency can be explored and maximized through this technique. This argument has been supported that student-centered learning model is aimed to develop students' activeness to respond every stimulus given, being focused, and build their necessity based on learning habits and interest of every student [17]. That can be said that mind mapping approach is much more oriented to draw students' activeness, which indirectly will lead them to classroom activeness culture that will help them build their thinking process.

The culture of thinking, for students in this case needs to be concerned and needs to be realized because thinking competency in each individual is a reflection of own self capacity. However, creating or situating that culture is not easy to be implemented toward students. There is phenomenon that one individual is able to think well and systematic without any assistance of media, there is also such individual that has such difficulties in shaping the thinking competence on their self. There is time that someone needs to put on their thought before uttering orally or in written form. They need to make any imagination or notes that possibly help them develop their though. It is in line with an idea which states that by noting or writing every object we see or think something in our mind help students to think and do analogy [18]. Noting activity or writing surely engages thinking process. When someone is writing, she or he absolutely thinks the object or concepts that are going to be typed. The effort to create the thought and idea or the efforts to re-utter past experiences saved in the memory are the main concern of thinking activity. Thinking activity in this case can be in the form of inserting any new information to be processed and saved or re-finding the past data in the memory. The role of memory determines the successful thinking activity. It is, in particular, determining students' successful learning process. This has been supported that memory contributes a positive manner in case of thinking activity, saving memory, and knowledge needed in time of doing thinking activity [19].

Mind mapping has similar functions as memory which means that mind mapping roles to save the experiences in term of images, symbols, and or words. Those images and symbols can be employed as prompt or hints for students in order to develop their mind. Mind mapping is actualized as an object which has arranged branches or twigs as a description of sequences and demands of images or symbols that exist in the twig. This is actualized to lead the logic thinking in order for students to follow the existed sequences within the twigs. That will eventually resulted to structured and systematic thinking activity. For that reason, mind mapping indirectly creates students thinking skill that is systematically structured.

\section{METHOD}

\section{A. Participant}

Participants in this study were 41 students in the second semester (University students in the academic year of 2017) in Mandarin education program, Mandarin department of State University of Surabaya. They are programming or taking the sociolinguistic subject and are divided into 10 big groups. This research is done within one semester (15 meetings) with the following classification: 7 meetings of discussing the theoretical concepts, 2 meetings of mind mapping prototype preparation guidance, 2 meetings of paper preparation process, and 4 final meetings of presenting and reflecting the project. The data is in form of observation result toward the students' performances in arranging the mind mapping prototype, developing idea and thought into the articles, presentation, and students masterpiece in form of mind mapping prototype as well as its development. The approach used was learning approach which has been developed as depicted in the chart I as in the following [20]. Meanwhile, the implementation of chart I is following another model [21]:

\section{CHART I. THE CONCEPTS OF STUDY BY MATOBA}

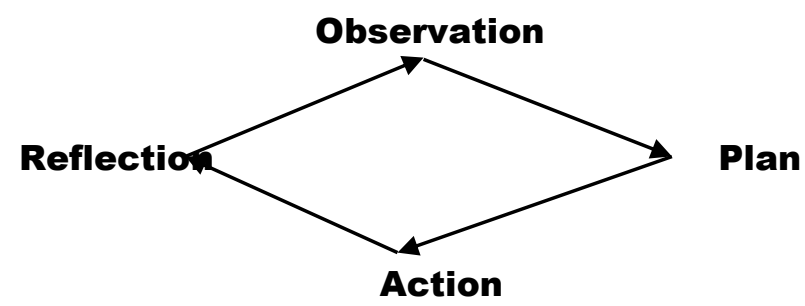

\section{B. Data Analysis}

Based on the type and form of data, the technique data analysis used is in form of descriptive analysis. It describes the phenomenon, action and any events that happen in every research data in each cycle.

\section{RESULT AND DISCUSSION}

\section{A. Cycle I}

1. Mind Mapping Prototipe

In this cycle I, all events are categorized in one focus to make the mind mapping prototype. For those who are quite familiar with the prototype will get the lecturer's guidance, they are directed to develop the basic concepts to be a narration. Based on the finding or the result of the direct observation when the process was done or based on the students' work, it is concluded that there are at least 9 groups which are able to make mind mapping prototype in a good form.

Those 9 works structurally have already met the requirement that consist of main element and developed element. The main element is a core of the theme, while the developed element is a part of the sub theme. The lack of those 9 works are commonly in case of placing the sub theme where the case happens in placing the wrong and inverse sub theme; also it does not represent the exact sub chapter. This happens because the students were unable to decide the related surrounding sub themes that contribute in solving the problem. 
The other problem happens that students were unable to give any solution in the cognate sub theme. As a result, among the cognate sub themes, the mapping looks like standing alone without any main theme. This case happens because students have not been accustomed with the similar colors alignment that has their own meaning. Those colors represent different images from each sub themes that still relates to sub theme for another sub theme in one group. The example of two above phenomena are depicted in Figure 1 below.

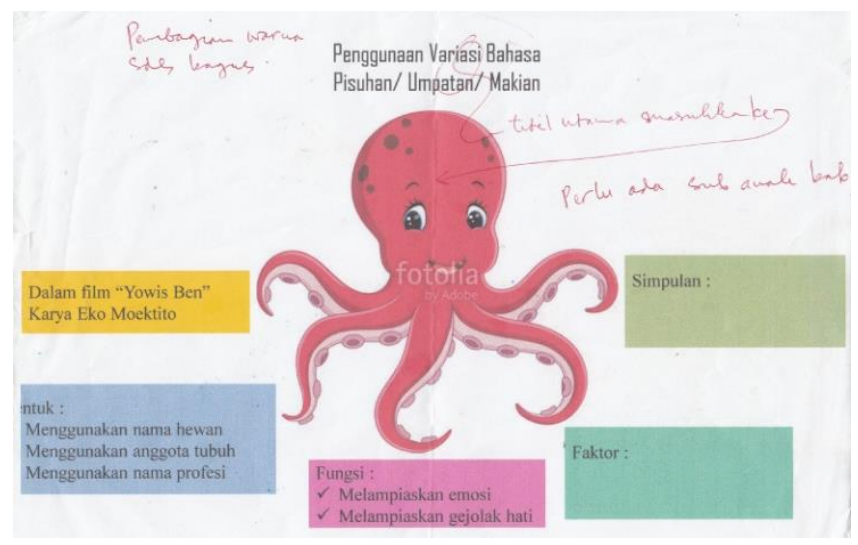

Fig.1. The example of work that has no alignment

The other students' works from different group still shows nothing but only showing the mind mapping structural profile, because in its structure, there has no any main element and development elements. From this result, it is assumed that students in this group hasn't fully able to comprehend the concept of mind mapping. The result of the mind mapping created by this group is depicted in the Figure 2 as follow.

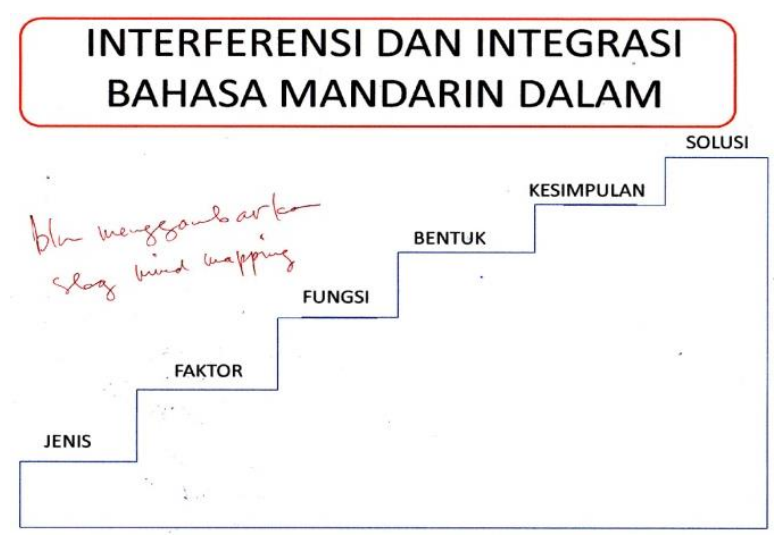

Fig.2. The Example of work that has not formed a mind mapping structure

After those all events, all groups were given guidance how to do a better mind mapping. The 9 group which have a basic knowledge of mind mapping were suggested to fix the mind mapping prototype, also they are given guidance to develop the concepts that has been written in the mind mapping prototype into narrative or descriptive form. The other group in the other hand does not have enough ability to fulfill the standard of mind mapping process. They are given explanation in order to recognize and understand the mind mapping as a whole. They were also guided until they are able to make a structure of mind mapping that is truly embedding the concepts that is presented within the mind mapping prototype. After guidance is done, all groups have in this case been able to arrange the mind mapping structural prototype well as portrayed in the $3 \mathrm{a}$ and $3 \mathrm{~b}$. Also, the other group which has no enough skills in this case has been able to improve their skill after guidance. It is depicted in Figure 3 and 4.

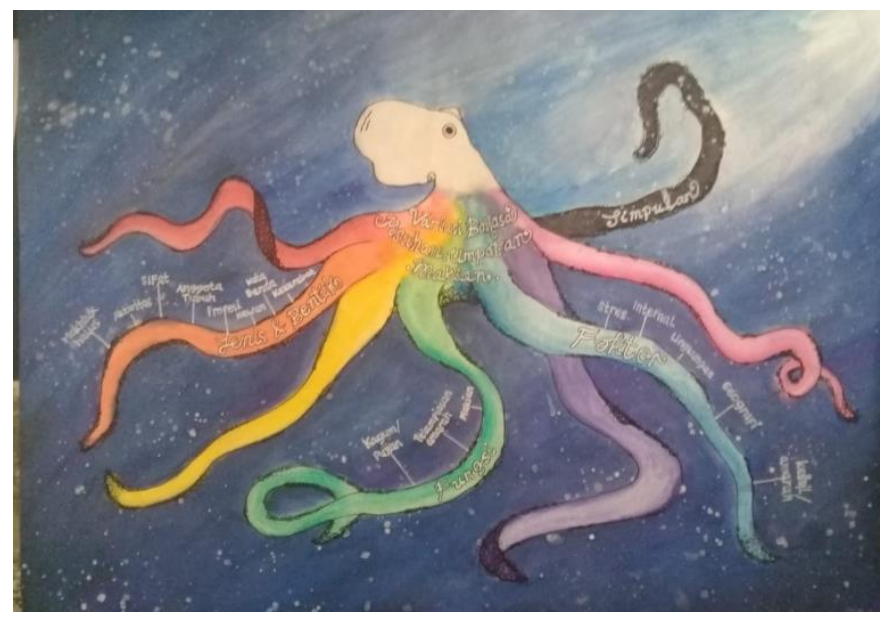

Fig.3. The result of improved colour alignment

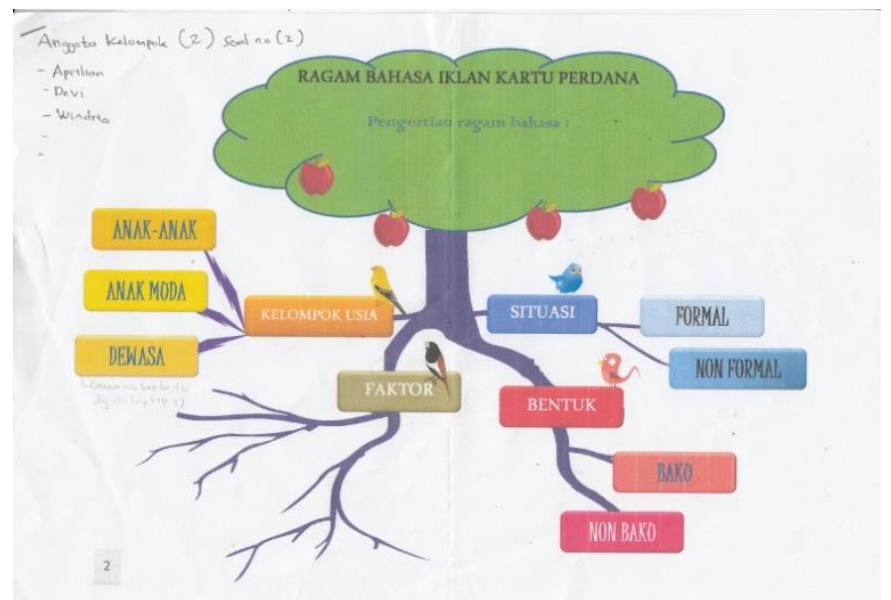

Fig.4. Improved results from Figure 2

In the process within the developing content to the narrative or descriptive form, all groups are able to do narration process smoothly even there is little bit problem encountered. Each group can do an idea development process even they have their own ability which is dissimilar.

There are three groups which are competent enough to perform the narrative development. Those three groups have their own idea development process that is faster if compared with the other seven groups. The seven other groups were able to do idea developmental process, however they tend to be slower and they are still guided by lecturer in case of hints like proposing questions or a direct suggestion. Based on the 
observation, while the process happens, it seems that students are still hesitate and feel uneasy to arrange the good sentence to be a good presentation from the idea to the systematical and arranged writing. For that reason, those seven groups need such priority in terms of guidance. Furthermore, in case of three other groups, their ability has shown a good result when it is connected to the main concept from the theory used with their group idea. However, when it is associated with their group idea to the theoretical relevant concept they are still having such difficulties. To deal with that problem, the lecture gave them guidance in order to give any solution. One of which is students were asked to seek for any theoretical concepts that deal with their own theme from any recommended literature from the lecturer.

\section{B. Cycle II}

The cycle II focuses on students' scientific works in the form of narration or description like the developmental concept result that has been go through cycle I in form of scientific work and direct presenting process either in oral or presentation.

Students' work in form of narration commonly meets the structural standard of a scientific research. The theme's coherency and continuity between sub chapter and sub theme is good already. It is then concluded that all group works is accepted when it is viewed structurally. This happens as a means of implementing mind mapping prototype that has already been prepared and has already been guided by lecturer. Students in this case are able to write the structured sub theme and sub- sub theme in accordance with the component of mind mapping. By this condition, it is very small probability that students do any mistakes. From the time view point, all groups can do their works by the agreed time; one week after the cycle I. They have collected all of their works on time. This shows that all groups have a speed level of composing their works. When it is viewed from the quantity aspect, all groups meet the minimum criterion, 10 pages excluding the references and 17 for the maximum pages. There are two groups which have performed 10 pages works. The thickest works is 13 pages. And the average page is between 11-12 pages. The cohesion and coherence aspect become a great challenge for all groups. The connection between sentences within one paragraph is still redundancy or not in the right position. The most common mistake is the sentence repetition in some paragraphs. This causes the narrative works to be ambiguous and the plot is cut. It then leads reader to reread the theme from the very beginning.

The other appearing problem is the sentence repetition that seems to wasting language that leads to the unfocused discussion and resulted on less language content. This shows that students are still lack in language efficiency and lack in performing assembling coherent ideas into narrative form

To deal with this problem, the lecturer give student such comments directly to the article paper or simply do oral guidance after presentation. Lecturer's feedback in form of notes is given back to every group that has presented and discussed. The ability to present the concept idea in oral is good and perfectly done within presentation process. Within 15 minutes, every group has done oral presentation alternately. Each group who perform presentation should be able to present the mind mapping prototype in the form of Microsoft PowerPoint. The presentation should be hyperlinked with the students' works. Based on the observation result, every student can perform good and smooth presentation even they are assisted by the slides of mind mapping prototype. Even the description is a way shorter if compared to students' written work when doing presentation, their works shows a solid, concise and clear language. It leads to fulfill the more effective and efficient aspect than students' works. The discussion theme presented is relatively coherent and continues. There is no statement' repetition and there is not found any misplaced themes idea so the plot is much easier to be followed and understood. From the fluency aspect, all groups can perfectly demonstrate their presentation. There is not found any silence due to obstacle in either substantial and in the form of presenting. When the lecturer confirmed in the discussion session, the presenters are able to give a good, conceptualized and smooth explanation. The lecturers also order students to include what they have presented. This issue claims that mind mapping structure helps student to get an easy access to reveal the idea that has been conceptualized before and presented in the form of symbols or and keywords within the particular spot of mind mapping.

Symbols and keywords can do their roles as a prompt from the whole concept in the brain. By implementing symbols or keywords in mind mapping, students are able to explore their saved-idea in the memory to be re-presented in form of narration. The fluency in the process of uttering back helps students to do thinking process in coherent and systematic concepts. That happens due to the existences $\mathrm{f}$ symbols or keywords presented in the structure of mind mapping

\section{CONCLUSION}

Mind mapping has a vital and significant role in students' thinking process in particular. The main component of the mind mapping structure functions as the starting point of an idea. It is classified into the development components. Symbols and keywords presented in the development component in mind mapping represent the interrelationship like in case of helping students to get lured to stimulate their thinking process. By doing this encouragement, students are able to rebuild their own memory to explore all the saved data in a coherent and continuous manner. Those data then arranged into a good sentence in either oral or written. It will eventually result on the good narrative text that represents students' idea and thought. The concept actualization process from the idea and thought is presented thought the prototype of mind mapping. This does help students a lot to train their thinking process. 


\section{REFERENCES}

[1] Iskandarwassid dan S. Dadang, "Strategi Belajar Bahasa", Remaja Rosdakarya Offset, Bandung, 2009.

[2] S. Wina, "Strategi Pembelajaran Berorientasi Standar Proses Pendidikan”, Kencana, Jakarta, 2007.

[3] A. Mariam and K. K. Poon, "Thinking and Learning Characteristics. In: Poon, Keneneth K. Educating Students With Autism Spectrum Disorders (Making Schools Meaningful)", Pearson, Jurong, Singapore, 2009.

[4] A. Buran and A. Filyukov, "Mind Mapping Technique in Language Learning", International Conference "Linguistic and Cultural Studies: Traditions and Innovations", LKTII 2015, pp. 215-218, 2015.

[5] A. W. Gunawan, "Born to be a Genius”, Gramedia, Jakarta, 2007.

[6] A. W. Gunawan, Genius Learning Strategy: Petunjuk Praktis Untuk Menerapkan Accelerated Learning vol. xxiii. Jakarta: Gramedia Pustaka Utama, 2004.

[7] R. M. Gagne, L. J. Briggs, and W. W. Wager, Principles of Instructional Design, 4th ed. USA: Ted Buchholz, 1979.

[8] B. Toni, 「マインド マップ」, dialih bahasakan oleh 近田美季子. 東京: ディスカヴァー・トゥエンティワン, 2008.

[9] 萩原京二・近藤哲生,「マインドマップ資格試験勉強法」 東京: ディスカヴァー・トゥエンティワン, 2009.

[10] B. Toni and B. Buzan,「ザ・マインドマップ」一脳の 無限の可能性を引き出す技術一東京 : ダイヤモンド, 2013.

[11] B. Toni, 「マインドマップ読書術」dialih bahasakan oleh 近田美季子. 東京 : ディスカヴァー・トウエンティワン, 2009.

[12] H. D. Brown, Teaching and Learning Language Principals. Jakarta: Kedutaan Besar Amerika Serikat, 2008.
[13] Fernandez, C., Learning from Japanese Approaches to Proffesional Development: The Case of Lesson Study. Jurnal of Teache Education 53 (5), pp. 393-405, 2002.

[14] M. Masami, Jugyoukiroku no Saikousei to Jugyoushoyouin no Shucchou ni Kan Suru Jikken Kenkyuu. Nagoya Daigaku Daigakuin Kyouiku Hattatsukagaku Kenkyuukakiyou. Vol. 3, pp. 148-161, 2008.

[15] H. Fergus P, Children, Play, and Development. 4th edition. SAGE Publications, 2010.

[16] Shin-Yin Lee, T. Graham and H. W. Stevenson., Teachers and Teaching: Elementary Schools in Japan and The United States. In: Teaching and Learning in Japan, Edited by Thomas P. Rohlen \& Gerald K. Le Tendre, Cambridge University Press, pp. 177, 1996.

[17] B. Mara, J. Davidson, and L. Flaxman, Small Schools Big Ideas - The Essential Guide to Successful School Transformation- San Francisco: Jossy-Bass, 2009.

[18] H. Thom, Teaching Second Language Reading. Oxford Handbooks for Language Teachers. New York: Oxford University Press, 2007.

[19] R. Robert and T. O. Lienemann, Strategy Instruction for Students with Learning Disabilities. New York: The Guilford Press, 2006.

[20] M. Masami. S. A. Mohammad, Jugyou Kenkyuu o Kiso to Shita Kounaikenshuu to Kyoushi no Shishitsu ni Kan Suru Kokusaikyoudou Kenkyuu (1). Iran ni Okeru Jugyoukenkyuu no Iten no Jirei. Nagoya Daigaku Daigakuin Kyouiku Hattatsukagaku Kenkyuukakiyou. Vol.50, no.1, pp. 146-161., 2003.

[21] Subandi, Peningkatan Keterampilan Berbicara Mahasiswa Bahasa Jepang Melalui Pendekatan Lesson Study dengan Menggunakan Materi Ajar Apresiatif. Dalam "Paramasastra" volume 1 No. 1, Maret 2014. pp. 92-108, 2004 